日植病報 $34: 289 \sim 297$ (1968)

Ann. Phytopath. Soc. Japan 34:289 297 (1968)

\title{
Variability in Indian Isolates of Xanthomonas oryzae (Uyeda and Ishiyama) Dowson, the Incitant of Bacterial Leaf Blight of Rice*
}

\author{
G. S. Shekhawat** and D. N. SRivastava**
}

\begin{abstract}
Variability in virulence, and some important physiological characters of 6 Indian isolates of Xanthomonas oryzae (Uyeda and Ishiyama) Dowson, the incitant of bacterial blight of rice and their sensitivity to antibiotics in vitro were investigated.

Morphologically, all the isolates were alike. However, with regard to cultural and physiological characters and antibiotic sensitivity, they could be divided into two groups. The first group comprised of 4 isolates, which were slower in growth in culture media with optimum temperature between $25-30^{\circ} \mathrm{C}$ and thermal death point between $51-52^{\circ} \mathrm{C}$, liquefied gelatin slowly, hydrolysed starch partially or not at all, gave alkaline reaction in litmus milk, did not produce hydrogen sulphide and were highly sensitive to all the 5 antibiotics tested, including penicillin. These isolates belonged to the highly virulent group. The other group comprised of 2 isolates, which grew faster on culture media with optimum temperature between $25-35^{\circ} \mathrm{C}$ and the thermal death point between $52-54^{\circ} \mathrm{C}$, liquefied gelatin rapidly, hydrolysed starch completely, gave acid reaction in litmus milk, produced hydrogen sulphide and were insensitive to penicillin and comparatively less sensitive to the other 4 antibiotics. These isolates were comparatively less virulent than the isolates of the first group.

(Received January 23, 1968)
\end{abstract}

\section{Introduction}

The bacterial leaf blight of rice, incited by Xanthomonas oryzae (Uyeda and Ishiyama) Dowson, which was known to be prevalent in a restricted area in Maharashtra since 1951 (Bhapkar et al, 1960), appeared in an epidemic form in Bihar during 1963 (Srivastava and Rao, 1963). With the widespread cultivation of the high yielding, nitrogen responsive but highly susceptible variety, Taichung Native-1, during the last 2 years, the disease has assumed panepidemic proportions all over India (Srivastava, 1967).

Considering the vascular nature of the disease and the vastness of the rice area in India, involving diverse climatic conditions and cultural practices, the best way to combat the disease is through utilization of host resistance, which is presently lacking in the commercial varieties. Before undertaking any work of screening and developing resistant varieties, it becomes essential to know the extent of variability in pathogenicity of isolates of the bacterium. Some work in this direction was carried out by Goto $(1965 \mathrm{~b})$ in the Philippines with local as well as Japanese isolates of the bacterium.

Further, conflicting reports have been published on some of the physiological characters of

* Based on thesis work of the senior author for the M. Sc. degree in plant pathology of the Indian Agricultural Research Institute, New Delhi, India.

** Division of Mycology and Plant Pathology, IARI, New Delhi, India. 
the bacterium, such as gelatin liquefaction, starch hydrolysis, hydrogen sulphide production, fermentation of carbon compounds and action on litmus milk (Breed et $\alpha l$, 1957; Chakravarti and Rangarajan, 1967 ; Elliott, 1957; Goto, 1964a, b; Ishiyama, 1922 ; Mukoo and Isaka, 1964; and Sulaiman and Ahamad, 1965).

This paper reports the results of investigations on pathogenic and physiological variability of 6 Indian isolates of the bacterium.

\section{Material and Methods}

\section{Isolates of the bacterium}

Pure cultures of 6 isolates of the bacterium listed below were employed for this study. They were obtained from the Section of Plant Bacteriology of the Division of Mycology and Plant Pathology of this Institute.

\begin{tabular}{c|l|l|c}
\hline Isolate & $\begin{array}{l}\text { Isolated from infected } \\
\text { leaves of rice variety }\end{array}$ & \multicolumn{1}{|c}{ Locality } & $\begin{array}{c}\text { Year of } \\
\text { isolation }\end{array}$ \\
\hline 1 & Taichung Native-1 & Mulpur (Andhra Pradesh) & 1966 \\
2 & Taichung Native-1 & Kalla (Andhra Pradesh) & 1966 \\
3 & Taichung Native-1 & Hyderabad (Andhra Pradesh) & 1966 \\
4 & Wild rice & Eluru (Andhra Pradesh) & 1966 \\
5 & BR-34 & Shahabad (Bihar) & 1965 \\
6 & Nagina-22 & Jagdishpur, Gorakhpur (Uttar Pradesh) & 1965 \\
\hline
\end{tabular}

The cultures were maintained on slopes of Potato Sucrose Agar under sterile mineral oil at $10^{\circ} \mathrm{C}$. Subcultures from these were grown for 48 hours on slopes of Potato Sucrose Agar at $30^{\circ} \mathrm{C}$ and used for all studies except for staining flagella where the age of the cultures was 24 hours.

\section{Composition of potato sucrose agar*}

Potato, peeled and diced $300 \mathrm{~g}$, peptone $2 \mathrm{~g}$, sucrose $20 \mathrm{~g}$, potassium phosphate $\left(\mathrm{KH}_{2} \mathrm{PO}_{4}\right) 0.2 \mathrm{~g}$, disodium phosphate $\left(\mathrm{Na}_{2} \mathrm{HPO}_{4} \cdot 12 \mathrm{H}_{2} \mathrm{O}\right) 0.2 \mathrm{~g}$, calcium nitrate $\left(\mathrm{Ca}\left(\mathrm{No}_{3}\right)_{2} \cdot 4 \mathrm{H}_{2} \mathrm{O}\right) 0.5 \mathrm{~g}$, potassium chloride $(\mathrm{KCl}) 0.5 \mathrm{~g}$, ferrous sulphate $\left(\mathrm{FeSO}_{\mathrm{l}}\right) 0.05 \mathrm{~g}$, agar $20 \mathrm{~g}$, distilled water to make up the volume to $1000 \mathrm{~m} l$.

Potato extract was prepared in $400 \mathrm{ml}$ of water and the agar was melted in another $400 \mathrm{~m} l$ of water. The rest of the ingredients were dissolved in $200 \mathrm{~m} l$ of warm water. All the three volumes were pooled and the final volume adjusted to $1000 \mathrm{~m} l$. The medium was strained through muslin and sterilized after adjusting the $\mathrm{pH}$ to 7.0 .

\section{Pathogenicity}

The method of host inoculation was similar to the one employed by Goto (1965 b). Using a set of 6 entomological pins (No. 20) fixed on a piece of cork, leaves of 5 week old plants of Taichung Native-1 were injured at a point mid-way between the tip and the base. One drop of

* Suggested by Dr. T. Mizukami of the National Institute of Agricultural Sciences, Nishi gahara, Tokyo, during one of his recent visits to this Institutute, 
the bacterial suspension ( 0.80 to 0.83 optical density) was smeared at the injured site by a glass rod. Twenty uniform leaves from different plants were inoculated with each isolate. Another 20 leaves were injured and smeared with sterile distilled water to serve as control. Observations were taken on the 15 th day. During this period, the average temperature and relative humidity ranged from 26.6 to $30.2^{\circ} \mathrm{C}$ and $86-96$ per cent, respectively. The weather, throughout this period, remained cloudy and rainy, thus providing ideal conditions for disease development. The results were based on average length of the lesions below the point of inoculation.

\section{Cultural and physiological characters}

The procedures employed were according to the Manual of Microbiological Methods (Society of American Bacteriologists, 1957). The synthetic basal medium recommended for the fermentation test of carbon compounds in the Manual could not be used for this bacterium because it requires organic nitrogen for growth (Goto, $1964 \mathrm{~b}$; Mohan, 1966). Therefore, the basal medium used by Goto was employed for this purpose. Thermal death point was determined according to Salle (1961).

\section{Sensitivity to antibiotics}

The isolates were tested for sensitivity to the following antibiotics by the paper disc method.

\begin{tabular}{ll|l}
\hline \hline 1. Streptomycin sulphate U.S.P. (Streptonex) & Pfizer Private Ltd., Bombay-1 \\
2. Chlortetracyclin hydrochloride crystalline & Lederle Laboratories (India) Ltd., Atal, P.O. \\
(Aureomycin) & Bulsar. \\
3. Oxytetracyclin (Terramycin) & Pfizer Private Ltd., Bombay-1 \\
4. Chloramphenicol U.S.P. (Chloromycetin) & $\begin{array}{l}\text { Parke Davis (India) Ltd., Saki Naka, Bombay- } \\
70\end{array}$ \\
& $\begin{array}{l}\text { Glaxo Laboratory (India) Private Ltd., } \\
\text { 5. Sodium penicillin G.B.P. (Crystapen) }\end{array}$ \\
\end{tabular}

Four $\mathrm{m} l$ of the bacterial suspension adjusted to an optical density of 0.80 was mixed with $80 \mathrm{~m} l$ of melted Potato Sucrose Agar pre-cooled to $45^{\circ} \mathrm{C}$. This was distributed equally in 4 sterilized Petri dishes. After the medium had set, 3 filter-paper discs $(1 \mathrm{~cm}$ in diameter) presoaked in 3 different concentrations of the antibiotic solution in phosphate buffer ( $\mathrm{pH} 7.0$ ) were placed equidistant over the medium. The Petri dishes were then incubated at $5^{\circ} \mathrm{C}$ for 2 hours to permit diffusion of the antibiotic in the medium, after which they were incubated at $30^{\circ} \mathrm{C}$. Observations on the zones of inhibition around the discs were taken at 48 hours. The test with each antibiotic was replicated six times. For controls, the discs were soaked in the buffer solution only.

Optical density adjustments of the bacterial suspensions were made by means of a Klett Summerson Photo-electric Colorimeter, using a filter of $420 \mathrm{~m} \mu$ wave length.

\section{Results}

\section{Pathogenicity}

From Table 1 , it is seen that the isolates varied considerably in their virulence, isolates 
Table 1. Pathogenicity of isolates of Xanthomonas oryzae on leaves of Taichung Native-1

\begin{tabular}{c|c}
\hline Isolates & Average lesion length $(\mathrm{cm})$ \\
\hline 1 & 15.2 \\
2 & 13.9 \\
3 & 10.1 \\
4 & 12.6 \\
5 & 7.6 \\
6 & 7.0 \\
Control & 0.0 \\
\hline
\end{tabular}

1,2 and 4 being more virulent than 3,5 and 6.

\section{Colony characters}

The isolates were grown on Potato Sucrose Agar and Nutrient Agar Plates at $30^{\circ} \mathrm{C}$ for comparison of colony characters.

On Potato Sucrose Agar, isolates 5 and 6 produced visible colonies at 72 hours, whereas in the other 4 isolates the colonies became visible at 96 hours. In all the isolates, the colonies were smooth, circular, convex, with entire margin glistening, whitish yellow at first, but barium yellow later and opaque against transmitted light.

On Nutrient Agar, the colonies of isolates 5 and 6 manifested at 120 hours and in the other 4 isolates, at 144 hours. The colonies of all the isolates were whitish yellow in the beginning, but became straw coloured with age. Other characters were the same as on Potato Sucrose Agar.

\section{Relationship of temperature to growth}

Potato Sucrose Agar slopes streaked with cell suspensions of the isolates were incubated at various temperatures and observed for growth at intervals of 24 hours for 15 days. The period at which the slightest visible growth occurred was recorded for each temperature.

From Table 2, it is seen that all the isolates grew between 5 and $40^{\circ} \mathrm{C}$, but failed to grow at 3 and $45^{\circ} \mathrm{C}$ during the test period of 15 days. Although, the growth was not assessed quantitatively, it is apparent that the optimum temperature for isolates $1,2,3$ and 4 was between

Table 2. Relationship of temperature to growth of isolates of Xanthomonas oryzae

\begin{tabular}{c|c|c|c|c|c|c|c|c|c|c}
\hline \multirow{2}{*}{ Isolate } & \multicolumn{10}{c}{ Days taken for visible growth at $\left(^{\circ} \mathrm{C}\right)$} \\
\cline { 2 - 10 } & $3^{\circ}$ & $5^{\circ}$ & $10^{\circ}$ & $15^{\circ}$ & $20^{\circ}$ & $25^{\circ}$ & $30^{\circ}$ & $35^{\circ}$ & $40^{\circ}$ & $45^{\circ}$ \\
\hline 1 & - & 13 & 8 & 6 & 3 & 1 & 1 & 2 & 4 & - \\
2 & - & 12 & 8 & 5 & 3 & 1 & 1 & 2 & 4 & - \\
3 & - & 13 & 8 & 5 & 3 & 1 & 1 & 2 & 3 & - \\
4 & - & 12 & 8 & 6 & 3 & 1 & 1 & 2 & 4 & - \\
5 & - & 12 & 7 & 5 & 3 & 1 & 1 & 1 & 2 & - \\
6 & - & 12 & 8 & 5 & 3 & 1 & 1 & 1 & 2 & - \\
\hline
\end{tabular}

-: No growth. 
25 and $30^{\circ} \mathrm{C}$, whereas for the other 2 isolates, it was between $25-35^{\circ} \mathrm{C}$. In all the isolates, the yellow pigment in the cultures was more intense at lower temperature $\left(5-20^{\circ} \mathrm{C}\right)$.

\section{Thermal death point}

The thermal death point of isolates $1,2,3$ and 4 was between $51-52^{\circ} \mathrm{C}$, whereas that of isolates 5 and 6 was between $52-53^{\circ} \mathrm{C}$.

\section{Physiological characters}

All isolates were strictly aerobic, produced ammonia, but failed to produce indole or reduce nitrate. All were negative with respect to Voges-Proskauer and methyl red tests. All produced acid without gas from glucose, sucrose and galactose, but none produced acid or gas from rhamnose, mannitol, glycerol and salicin. A comparison of some other physiological characters is presented in Table 3.

Table 3. Physiological characters of isolates of Xanthomonas oryzae

\begin{tabular}{c|c|c|c|c|c|c|c|c}
\hline \hline \multirow{2}{*}{ Isolate } & $\begin{array}{c}\text { Gelatin } \\
\text { lique- } \\
\text { faction }\end{array}$ & $\begin{array}{c}\text { Starch } \\
\text { hydrolysis }\end{array}$ & $\begin{array}{c}\text { Hydrogen } \\
\text { sulphide } \\
\text { production }\end{array}$ & \multicolumn{2}{|c|}{ Action on litmus milk } & \multicolumn{2}{c|}{$\begin{array}{c}\text { Fermentation of } \\
\text { carbon compounds } \\
\text { (Acid without gas) }\end{array}$} \\
\hline 1 & + & + Acid & Curd & $\begin{array}{c}\text { Peptoni- } \\
\text { (ation }\end{array}$ & Lactose & Dextrin \\
\hline 2 & + & - & - & - & - & - & - & - \\
3 & + & $+(\mathrm{p})$ & - & - & - & - & - & - \\
4 & + & - & - & - & - & - & - & - \\
5 & + & + & + & + & + & - & - & - \\
6 & + & + & + & + & + & + & + & + \\
\hline
\end{tabular}

+ : Positive, H: Rapid, +(p): Positive but partial, - : Negative.

(i) Gelatin liquefaction: All the isolates liquefied gelatin. Isolates 5 and 6 started liquefaction at 48 hours and completed on the 15th day. In the other 4 isolates, it commenced on the 11 th day was not complete till the 30 th day. The form of liquefaction in all the isolates was napiform.

(ii) Starch hydrolysis: Isolates 5 and 6 hydrolysed starch completely within 48 hours, isolates 1 and 3 did so only partially at 7 days, but could not effect complete hydrolysis even till the 15th day, whereas isolates 2 and 4 did not hydrolyse starch at all upto the 15th day.

(iii) Hydrogen sulphide production: Isolates 5 and 6 produced hydrogen sulphide within 48 hours, but the other 4 isolates failed to do so even upto the 15th day.

(iv) Action on litmus milk: None of the 6 isolates reduced litmus. Isolates 5 and 6 produced acid reaction at 48 hours, resulting in curdling of the milk. The curd settled at the bottom, leaving a clear red coloured liquid at the top. These isolates peptonized the milk only partially till the end of the test period. The other 4 isolates turned the milk slightly acidic at 48 hours without curd formation, but the pink colour formed due to the acidity gradually changed to blue, starting from the top downwards and, at 8 days, it turned completely blue. There was no peptonization or change in the consistency of the milk by these 4 isolates.

However, when this test was performed at $18-20^{\circ} \mathrm{C}$, isolates 5 and 6 did not differ from the other 4 isolates in respect to their action on litmus milk. 


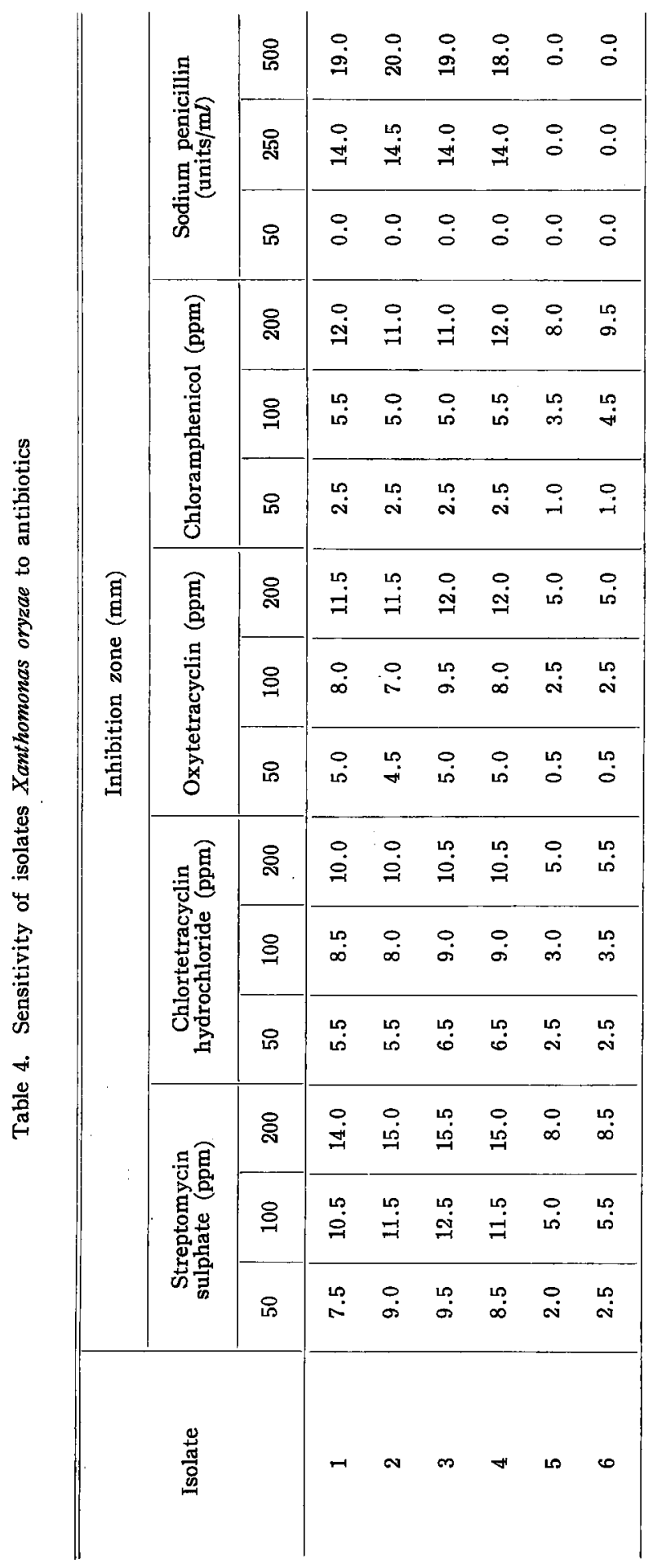


(v) Fermentation of carbon compounds: Isolates 5 and 6 produced acid without gas in lactose and dextrin after 4 days, but the other 4 isolates did not ferment these compounds at all till the 30 th day.

\section{Sensitivity to antibioties}

From the results in Table 4 , it is seen that all the 6 isolates were sensitive to streptomycin sulphate, chloramphenicol, chlortetracyclin hydrochloride and oxytetracyclin to various degrees, the inhibition zones in isolates $1,2,3$ and 4 being nearly twice as much as in isolates 5 and 6 . Among these 4 antibiotics, all the isolates showed greater sensitivity to streptomycin sulphate, the inhibition zones at $50 \mathrm{ppm}$ being comparable to $100 \mathrm{ppm}$ of the other 3 . To penicillin, isolates $1,2,3$ and 4 proved sensitive at 250 units $/ \mathrm{m} l$, whereas the other 2 isolates were insensitive to this antibiotic even at a concentration of 1000 units/ml.

\section{Discussion}

From the extent of variability in virulence observed among 6 isolates, one may be inclinded to advocate the use of the most virulent isolate in screening rice varieties for resistance. However, at present, there is no information available on specialized pathogenic races of the bacterium from any quarter of the world. Therefore, it becomes essential to include the less virulent ones in mixture with the virulent isolates in any varietal screening programme.

It is seen from the results that the 6 isolates belonged to 2 distinct groups. Isolates $1,2,3$ and 4 failed to produce hydrogen sulphide in peptone water, and acid from lactose and dextrin, liquefied gelatin slowly, hydrolysed starch partially or not at all, gave alkaline reaction in litmus milk without curd formation or peptonization, were more virulent and were sensitive to penicillin. On the other hand, isolates 5 and 6 produced hydrogen sulphide, acid from lactose and dextrin, liquefied gelatin fast, hydrolysed starch completely, gave acid reaction in litmus milk

Table 5. Comparison of some physiological characters of Xanthomonas oryzae as reported by various workers

\begin{tabular}{|c|c|c|c|c|c|c|c|c|}
\hline & \multicolumn{8}{|c|}{ Characters per source } \\
\hline & \multicolumn{2}{|c|}{ Present isolates } & \multirow{2}{*}{$\mid \begin{array}{c}\text { Bergey's } \\
\text { Manual } \\
1957\end{array}$} & \multirow{2}{*}{$\begin{array}{c}\text { Chakra- } \\
\text { varti } \\
\text { and } \\
\text { Ranga- } \\
\text { rajon } \\
1957\end{array}$} & \multirow{2}{*}{\begin{tabular}{|c|} 
Goto \\
$1964 \mathrm{a}, \mathrm{b}$
\end{tabular}} & \multirow{2}{*}{$\begin{array}{c}\text { Ishi- } \\
\text { yama } \\
1922\end{array}$} & \multirow{2}{*}{$\begin{array}{l}\text { Mukoo } \\
\text { and } \\
\text { Isaka } \\
1964\end{array}$} & \multirow{2}{*}{$\begin{array}{c}\text { Sulai- } \\
\text { man } \\
\text { and } \\
\text { Ahamad } \\
1965\end{array}$} \\
\hline & $1,2,3 \& 4$ & 5 and 6 & & & & & & \\
\hline Gelatin liquefaction & + & + & - & + & + & - & + & - \\
\hline Starch hydrolysis & - or $+(p)$ & + & - & + & - & ? & - & - \\
\hline $\begin{array}{l}\text { Hydrogen sulphide } \\
\text { production }\end{array}$ & - & + & + & + & + & - & + & - \\
\hline Action in litmus milk & Alkaline & Acidic & $\begin{array}{c}\text { Slightly } \\
\text { acidic }\end{array}$ & Alkaline & Alkaline & Slightly & Alkaline & Acidic \\
\hline Ammonia production & + & $t$ & $?$ & + & + & - & + & - \\
\hline $\begin{array}{l}\text { Fermentation of carbon } \\
\text { compounds. }\end{array}$ & & & & & & & & \\
\hline Lactose & - & + & + & + & - & $?$ & $?$ & $?$ \\
\hline Dextrin & - & + & $?$ & $?$ & - & $?$ & - & $?$ \\
\hline
\end{tabular}

+ : Positive, $+(p)$ : Positive but partial, - : Negative, ?: Not reported. 
with curd formation and peptonization, were less virulent and were insensitive to penicillin.

Mukoo and Isaka (1964) reported that there was a direct correlation between the ability to liquefy gelatin and virulence of the isolates, but the results of the present studies were just the reverse.

A comparison of physiological characters of these isolates with those reported by other workers from various parts of the world is given in Table 5. The Table makes it abundantly clear that many of the important physiological characters of Xanthomonas oryzae are highly variable. It would be, therefore, incorrect to assign a particular physiological property as a characteristic of this organism.

The antibiotic sensitivity test revealed that all the isolates were sensitive to streptomycin sulphate, chloramphenicol, chlortetracyclin hydrochloride and oxytetracyclin to various degrees. Isolates 1, 2, 3 and 4 were sensitive to penicillin also and were more sensitive to the above 4 antibiotics than isolates 5 and 6 which did not show any sensitivity to penicillin even at concentration of 1000 units $/ \mathrm{m} l$. Among the 5 antibiotics tested, streptomycin sulphate was decidedly more effective at all concentrations. It would be important to screen larger number of isolates to find out if any strain of the pathogen resistant to streptomycin exists in this country.

\section{Acknowledgement}

The authors are grateful to Mr. Y. P. Rao, Assistant Plant Bacteriologist, for his ungrudging help from time to time and to Dr. S. P. Raychaudhuri, Head of the Division of Mycology and Plant Pathology, for kindly providing facilities and encouragement in this work. Thanks are also due to Messrs J. C. Durgapal and J. K. Jindal for their assistance. The senior author expresses his gratitude to the Rockefeller Foundation for the award of part-time assistantship for these investigations.

\section{Literature cited}

1. Bhapkar, D. G., Kulkarni, N. B. and Chavan, V. M. (1960). Poona Agric. Coll. Mag. 51: 36-46.

2. Breed, R. S., Murray, E. D. G. and Smith, N. R. (1957). Bergey's Manual of Determinative Bacteriology. 7th ed. Baltimore, Md. p. 1094.

3. Chakravarti, B. P. and Rangarajan, M. (1967). Phytopathology 57:688-690.

4. Elliott, C. (1951). Manual of Bacterial Plant Pathogens. 2nd ed. Waltham Mass. p. 186.

5. Goto, M. (1964 a). Pl. Dis. Reptr. 48: 858-861.

6. Goto, M. (1964 b). Rep. Fac. Agr. Shizuoka Univ. Japan $14:$ 3-10.

7. Goto, M. (1965). Philippine Agriculturist 48: 329-338.

8. Ishiyama, S. (1922). Jap. J. Bot. 1 (1923) Abstract 21.

9. Mohan, S. K. (1966). Studies on nutrition of Xanthomonas oryzae (Uyeda and Ishiyama) Dowson, the incitant of bacterial blight disease of rice. M. Sc. Thesis, Indian Agricultural Research Institute, New Delhi. p. 49.

10. Mukoo, H. and Isaka, M. (1964). Ann. Phytopath. Soc. Japan 29 : 13-19.

11. Salle, A. J. (1961). Laboratory Manual on Fundamental Principles of Bacteriology. New York. p. 201.

12. Society of American Bacteriologists (1957). Manual of Microbiological Methods. New York. p. 315 . 
13. Srivastava, D. N. and Rao, Y. P. (1963). Indian Phytopath. 16: 393-394.

14. Srivastava, D. N. (1967). Symposium on rice diseases and their control by growing resistant varieties and other measures. Agriculture, Forestry and Fisheries Research Council, Ministry of Agriculture and Forestry, Japan pp. A-1-A-15,

15. Sulaiman, M. and Ahamad, L. (1965). Indian Farming 15: 27-29.

\title{
和文摘要
}

\section{インドのイネ白葉枯病菌 [Xanthomonas oryzae (Uyeda et Ishiyama) Dowson] 菌株の変異性}

\author{
G. S. Shekhawat \& D. N. SRivastava
}

䍜病葉から分離したイネ白葉枯病菌 [Xanthomonas oryzae (Uyeda et Ishiyama) Dowson] の6 菌株 を用いて，それらの病原力，主要な生理学的諸性質およびin vitro に括ける抗生物質に対する感受性の差異 を比㜞した。

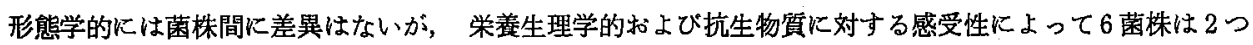
のグループに分けられる。

第 1 のク゚ループには，6 菌株中 4 菌株が含まれ，これらは培地上での生育が遅く，生育適温は $25 \sim 30^{\circ} \mathrm{C}$, 死隇温度は $51 \sim 52^{\circ} \mathrm{C}$ ，ゼラチンを徐々に溶解し，揤粉をわずかに分解するかあるいはほとんど分解しない。 リトマスミルクを青変し，硫化水素を生産せず，供試した 5 種類の抗生物質にすべて感受性を示す。病原力 はすべて強大である。

第 2 のグループは残りの 2 菌株であるが，いずれも培地上での生育が早く，生育適温は $25 \sim 35^{\circ} \mathrm{C}$, 死減温 度は $52 \sim 54^{\circ} \mathrm{C}$ ， ゼラチンを速かに溶解し，搌粉を完全に分解する。リトマスミルクを赤变し，硫化水素を 生産し，ベニシリンに抵抗性を示すほか他の 4 種の抗生物質に対しても此較的感受性が低い。そして病原力 は第1のグループよりる弱い。 